\title{
Solar energy discourse in the Sunshine State
}

\author{
Prisca Augustyn ${ }^{1}$
}

\begin{abstract}
This case study of a 2016 Florida constitutional amendment analyses the semiotic devices and mechanisms of shaping public opinion on solar energy and beliefs about energy distribution. After a nationwide rise in rooftop solar installations between 2014 and 2015, utilities in several US states were faced with challenges to their business models. Anticipating similar problems in Florida, utilities and energy corporations promoted constitutional amendments. This semiotic analysis follows the voter from the billboards and flyers to the text on the ballot. Starting from Peirce's phenomenological categories, this critical analysis of the campaign reveals how the goals of the amendment were shrouded in positive environmental and consumer protection narratives. Lakoff's cognitive linguistics and Stibbe's ecolinguistics support a deeper analysis of the ballot text. This study shows that by leaving key concepts (especially net metering) out of the discourse, the ballot text successfully framed an anti-solar amendment as a pro-consumer measure, while hiding the direct legal implications concerning alternative energy distribution. In particular, this study explains the opposition to the sharing of surplus in the context of neoclassical economics as a key factor in shaping beliefs about alternative energy distribution.
\end{abstract}

Keywords: 2016 Florida solar amendment; energy distribution; net metering; Peirce's phenomenological categories; progressive vs. conservative modes of thought; framing; ecolinguistics

\section{Introduction}

With a population of 21 million, Florida has become the third most populous state in the US after California and Texas. Even though Florida is the second largest producer of electricity in the United States after Texas, the Sunshine State ranks surprisingly low in solar energy production and consumption. More than twothirds of Florida's net electricity is generated from natural gas. In 2017, roughly one-sixth of Florida's net electricity generation came from coal. There are two

1 Department of Languages, Linguistics, and Comparative Literature, Florida Atlantic University, 777 Glades Rd, Boca Raton, FL 33431, USA; e-mail: augustyn@fau.edu. 
nuclear power plants on the Atlantic Coast that produce most of the remaining net electricity. Almost all of the state's recent and planned capacity additions will be fuelled by natural gas. Although Florida is one of the top producers of electricity in the US, it does not meet current state power demand. The residential sector consumes more than half of the electricity used in Florida, air-conditioning being an important factor. Less than 3\% of Florida's electricity comes from renewable sources, primarily biomass (mostly waste from the sugar and citrus industries). (All data retrieved from Energy Information Administration 2018). ${ }^{2}$

According to a report from the Solar Energy Information Association SEIA (Muro, Saha 2016), US solar installations reached one million in 2016 nationwide. The report confidently forecast a consistent increase in both utility-scale and residential photo-voltaic installations for the following years. Residential solar installations in the US had surged by $66 \%$ between 2014 and 2015 (Muro, Saha 2016). This created challenges for utilities and the Public Utility Commissions that regulate them.

\begin{abstract}
Specifically, the proliferation of rooftop solar installations is challenging the traditional utility business model by altering the relationship of household and utility - and not just by reducing electricity sales. In this respect, the solar boom has prompted significant debates in states like New York and California about the best rates and policies to ensure that state utility rules and rates provide a way for distributed solar to flourish even as utilities are rewarded for meeting customer demands. (Muro, Saha 2016)
\end{abstract}

The 2014/2015 boom in residential solar installations and the ensuing challenges and debates about new distribution models inspired the proposal of constitutional amendments for the 2016 election cycle in Florida. Utilities were concerned about too many customers producing energy from sources like rooftop solar that would make their current business model unsustainable. Only two amendments were approved to go on the ballots. Amendment $4^{3}$, concerning property tax exemptions for renewable energy devices, was included in the August 2016 ballot. Amendment 1, the more complex measure and main focus of this paper, was included in the November ballot of the 2016 Presidential election. The purpose of Amendment 1 was to discourage rooftop solar installations and maintain the old distribution system while appearing to be supportive of solar energy.

2 Energy Information Administration 2018. Florida State Energy Profile. Retrieved in October 2018 from https://www.eia.gov/state/print.php?sid=FL\#112.

3 See Miami Herald Editorial Board 2016. 


\section{Amendment 1 for the sun? The semiotics of billboards and ballots}

To understand the process of arriving at a decision on whether to say 'yes' or 'no' to a proposed measure, it is worth exploring the semiotic practices associated with the promotion of constitutional amendments. Long before the election, voters encounter ad campaigns in their mailboxes or on billboards along the freeway that reduce a political measure to a simple slogan that usually highlights the amendment number and the words 'yes' and 'no'. Amendment 1 was represented by the slogan "Yes on 1 for the sun" 4 accompanied by a visual design of a sunrise in yellow/orange and navy blue text (see Fig. 1).

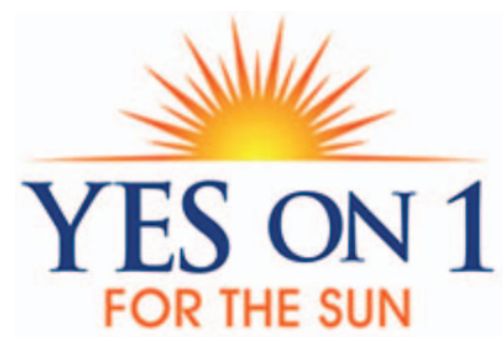

Figure 1. Yes on 1 for the sun.

The choice of colours is not indicative of any party affiliation. The colours evoke generic feelings of positivity, a sunrise on the horizon, leaving the voter positively uncertain of what exactly Amendment 1 is going to achieve for the sun. The slogan cannot be taken literally, because no constitutional amendment on this planet can make any difference for the Sun. The only inference we can make from the visual design is a positive feeling towards Amendment 1.

More could be said about the typographical choices employed in the design. They create an overall optimistic and congratulatory feeling. Peirce's phenomenological categories are effective in analysing what this kind of visual design can achieve in terms of marketing the amendment to the voter. In section 1 of "What is a sign?" (1894), Peirce (EP2: 4) explained that "[Firstness] is about as near as may be to a state of mind in which something is present, without compulsion and without reason; it is called Feeling". Without any context or explanation, this ad is unlikely to take the uninitiated reasoner far beyond an initial feeling, partly

4 Consumers for Smart Solar. Retrieved October 2018 from https://smartsolarfl.org. 
because it is not a logical proposition to be for the sun. The immediacy of Firstness is undeniably the goal of the design. In Section 2, Peirce (EP2: 5) explains that:

[there] are three kinds of interest we may take in a thing. First, we may have a primary interest in it for itself. Second, we may have a secondary interest in it, on account of its reactions with other things. Third, we may have a mediatory interest in it, in so far as it conveys to a mind an idea about a thing.

All three are present in the cognitive iterations we devote to the signs we engage with, but Firstness remains on the level of feeling rather than thought, and often we are content with that. Voters who have an interest in solar energy, may feel compelled to investigate, and therefore react to the campaign in search for more information in order to arrive at a better idea about whether to support the amendment or not. Peirce's explications about conscious thought and pragmatism are helpful in explaining how this representation of the amendment was constructed and why. In "Of reasoning in general" (1895), Peirce (EP2: 11-26) describes logic as the art of reasoning through his basic typology of signs and returns, once again, to the phenomenological categories. Here he explains the nuances of the conscious state of feeling with the concept of subjective intensity in analogy with objective intensity (e.g. a loud sound vs. a faint one). Peirce (EP2) explains that there are degrees in which we perceive. The visual design and message of the ad for Amendment 1 are crafted precisely to not take the viewer to a reaction or thought and merely create a positive or neutral feeling. Just like objective intensity (e.g. a faint noise $v s$. a loud one), subjective intensity can reach from very low to very high. Peirce illustrates subjective intensity with the example of hearing the ticking of a clock very loudly when the conscious mind perceives it with high intensity. The visual design and linguistic message of "Yes on 1 for the sun", undeniably low in objective intensity, is intended to keep the viewer in a state of low subjective intensity. While it keeps the complacent viewer content, it leaves the skeptical viewer to intuition rather than inference. Peirce gives the example of meeting a stranger who gives an impression of being dishonest:

[...] owing to indications too slight for me to know what they are. Yet the impression may be well founded. Such results are usually set down to intuition. Though inferential in their nature, they are not exactly inferences. (EP2: 11)

Peirce pointed out that some of our thoughts are subconscious when he wrote that "thought is all the time going on, not merely in that part of consciousness which thrusts itself upon attention, but also those parts that are deeply shaded" (EP2: 23). This "dishonest stranger" may seem suspicious to the highly perceptive, but 
may appear sunny to those whose subjective intensity is low. Like the clock ticking in the background, you may drive along the freeway and merely feel good about Yes on 1 for the sun. Only those who are informed and willing to invest more in an issue may hear the clock ticking more loudly and feel compelled to seek more clarity of thought.

The opposition backed by a group called Floridians for Solar Choice ${ }^{5}$ responded to "Yes on 1 for the sun" with the slogan "Utility-backed Amendment 1 blocks the sun" and the imperative to "Vote no on 1" (see Fig. 2).

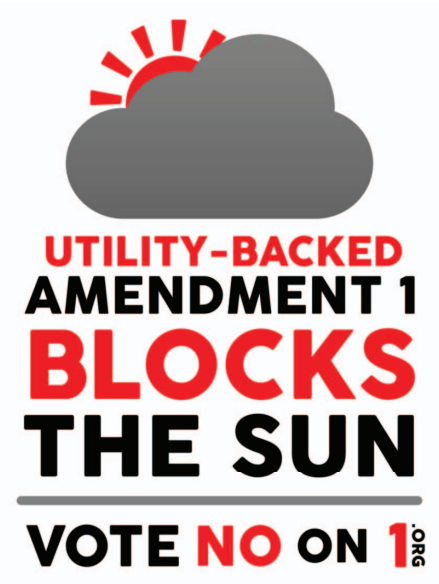

Figure 2. Amendment 1 blocks the sun.

The warning red and black letters in this design convey urgency and danger, thereby increasing the objective intensity of the design. A dark gray cloud blocks most of a red sun that seems to be in danger of disappearing completely. Typographically, it resembles cautionary signs like the ones that warn of slippery floors, high voltage, or hazardous materials. The most important fact offered by the opposition message is that Amendment 1 was "utility-backed", thereby igniting the enquiring voter's inferential engine. This fact finally allows for an outward observation that compels the viewer to a reaction. This design clearly demands inference beyond intuition. The metaphor of the amendment 'blocking the sun' calls for analytical thought to unravel the analogy represented in the visual design.

5 Floridians for Solar Choice. Fact sheet on Amendment 1. Retrieved in October 2018 from http://www.flsolarchoice.org. 
How can a political measure block the sun? It is interesting that the opposition's slogan is repeating the phrase 'the sun' when the real concern is solar energy harvested here on Earth. Why not be more precise and say 'blocks solar (energy)'? There are, as we shall see, more instances of simplifying the discourse at the expense of clarity that have unnecessarily obscured the discourse on both sides. On this issue, Peirce explained that "there is a great distinction between reasoning which depends on the laws of the inner world than reasoning which depends on the laws of the outer world" (EP2: 24). While outward observation and scientific logic are the only types of inference that rely on the laws of nature, Peirce recognized that much of our reasoning relies on inward observation.

It is interesting to note that there were several amendments concerning solar energy that did not make it on the ballot in 2016. The two that were selected were numbered 1 and 4 . Aside from conveniently rhyming with the word sun, the placing of this amendment as Amendment 1 in the 2016 election cycle is significant and attests to the strong influence of its proponents.

Before the election, registered voters receive a sample ballot in the mail through the Supervisor of Elections in their county. For the curious voter, this is usually the first encounter with the ballot text. Depending on party affiliation, voters may receive voter guides and flyers in the mail or through social media that seek to explain the amendments. This fact alone is indicative of the low readability of ballot texts and the accepted necessity of translation. Voters may also receive advertisements in favour or against amendments directly from the interest groups sponsoring them or the opposition. The sanguine voter may trust that the facts will be clearly presented in the ballot text and they can simply read through the ballot and make a decision on whether to support it or not right after reading through it at the precinct. For many voters, it is in the voting booth where they encounter the ballot text for the first time:

\section{Rights of Electricity Consumers Regarding Solar Energy Choice ${ }^{6}$}

This amendment establishes a right under Florida's constitution for consumers to own or lease solar equipment installed on their property to generate electricity for their own use. State and local governments shall retain their abilities to protect consumer rights and public health, safety and welfare, and to ensure that consumers who do not choose to install solar are not required to subsidize the costs of backup power and electric grid access to those who do.

6 Department of State. Constitutional Amendments. Retrieved in October 2018 from https://dos. myflorida.com/media/696216/constitutional-amendments-2016-general-english-booklet.pdf. 
On a cursory reading, the title of the amendment highlights the notion of rights and choice for the consumer. The text consists of two long sentences of low readability. Even experienced readers may need a few iterations to keep track of the syntactic structure of these two sentences. Most readers are likely to perceive the nouns as a string of concepts. The ballot text, then, reads like a list of things such as rights for consumers and the government protecting these rights, their health, and safety, and making sure nobody has to subsidize backup power for the solar users. Before going into a detailed analysis of the ballot text, some background on its proponents and their goals will be helpful.

\section{Who are the Consumers for Smart Solar?}

The opposition did well to insert utility-backed into their ad, because Amendment 1 was sponsored by a group of utility and energy corporations called Consumers for Smart Solar. The sponsors of the political action committee (PAC) included no consumers at all, but Florida's largest utility provider Florida Power \& Light, as well as energy corporations like Duke Energy, Exxon Mobile, Gulf Power, Tampa Electric Company, NRECA, and Koch Brothers. The Miami Herald, among others, drew attention to the fact that:

[...] investor-owned utilities poured more than $\$ 20$ million into the political committee backing the initiative, Consumers for Smart Solar. A handful of other groups, which were also heavily financed by utilities, spent another $\$ 6$ million promoting the amendment. (Klas 2016b)

The campaign slogan "Yes on 1 for the sun" erased all other stories (cf. Stibbe 2015) and created the impression that a 'yes' vote for Amendment 1 was simply a vote for more solar energy. The concept of erasure in Stibbe's (2015: 155) ecolinguistics is a key strategy of redirecting attention in a narrative. Stibbe's (2012) prime example is the erasure of animals from food narratives. This allows the crafting of stories where key ideas are simply erased. It makes it possible to talk about steak and hamburgers without talking or thinking about cows. Here we are presented with a story about solar energy without talking or thinking about how it is produced and sold and by whom.

The name Consumers for Smart Solar for a PAC sponsored exclusively by investor-owned utilities and energy corporations alerted the attention of semiotically sensitive or well-informed observers, much like a 'dishonest stranger' (EP2: 11) at first through intuition rather than inference. To draw attention to the identity of 
the sponsors of the amendment, a commentary on the Energy and Policy Institute from October 24, 2016, noted that:

CSS [Consumers for Smart Solar] has nothing to do with consumers. They're certainly not for solar. Maybe it's time for CSS to change its name? They could try 'Utilities and Front Groups for Monopoly Profits'. (Energy and Policy Institute, October 24, 2016)

The "Yes on 1 for the sun" campaign reduced the real purpose of the measure to a single simple story that the voter could interpret as promoting solar energy in Florida when the real intentions behind the measure were the exact opposite. The ballot text, however, presented a complex set of narratives revolving around the rights and choice of the consumption of renewable energy, the devices and their installation, and the potential challenges of ownership and operation. First and foremost, they focused on framing voters as CONSUMERs in a narrative that appeals to both conservative and progressive minds alike.

\section{Conservative and progressive modes of thought}

In the context of political discourse in the Unites States, Lakoff (e.g. 2004, 2008, 2010) has offered an analysis of what he calls progressive and conservative modes of thought and their associated discourse practices. His work aims to explain not merely the difference between conservative and progressive points of view, but modes of thought that inform how individuals construct narratives of particular issues regardless of their political orientation. Most people, according to Lakoff, use both conservative and progressive modes of thought:

People who call themselves 'conservatives' may use progressive modes of thought in certain issue areas. Conversely, people who call themselves 'liberals' may think in a conservative mode in certain issue areas. (Lakoff 2008: 3 )

He aims to explain the "political unconscious of individual citizens" (Lakoff 2008: 13), because what he calls the "old Enlightenment view of reason is not sufficient for understanding our politics" (Lakoff 2008: 15). What Peirce called "inward reasoning" (EP2: 26) based on feeling is solidified by repeated narratives rather than facts and logical conclusions. Lakoff suggests that most people are 'biconceptual', using progressive and conservative modes of thought. Rather than factual and objective, reasoning is emotional and subjective, based on the narratives that have established themselves in our neural pathways. Lakoff (2008: 15) explains that: 
Language gets its power, because it is defined relative to frames, prototypes, metaphors, narratives, images, and emotions. Part of its power comes from its unconscious aspects: we are not consciously aware of all that it evokes in us, but it is there, hidden, always at work. If we hear the same language over and over, we will think more and more within the frames and metaphors activated by that language. And it doesn't matter if you are negating words or questioning them, the same frames and metaphors will be activated and hence strengthened.

Lakoff (2008: 34) draws on neuroscience to argue that "narratives are fixed in the neural circuits of our brains", which create habits of thought that actively hide realities that contradict them. This explains why people adopt the cognitive habits of the people and discourses they live with. Lakoff's work is consistent with recent efforts among discourse analysts to explain opposing views of an issue equally instead of always taking a 'critical' perspective. In order to achieve this, discourse analysts like Fairclough and Fairclough (2018) depend on the key concepts of cognitive linguistics:

Critical discourse analysis equally highlights the importance of framing in political discourse, because 'the point of representing (or 'framing') an issue in a particular way is to create particular public attitudes and opinions, and thus legitimize or facilitate a particular course of action. (Fairclough, Fairclough 2018: 170)

According to Lakoff, however, those who live by the conservative modes of thought are better at framing issues in a way that represents their values effectively. That means they know their values and goals and then frame them accordingly. One of his primary examples is taxation. Conservative modes of thought in the US context come from valuing individual freedom and independence. Frames like TAX BURDEN OR TAX RELIEF represent these values of self-interest and the story of EVERY MAN FOR HIMSELF. Progressive modes of thought, on the contrary, are rooted in empathy, concern for the community, the well-being of others, and the environment. If progressives enter the discourse on TAX RELIEF, they are perpetuating the frame of conservative modes of thought simply by using the concept TAX RELIEF and thereby fail to frame their own values (based on empathy) effectively.

Conservative modes of thought, according to Lakoff $(2004,2008)$, are rooted in discipline and authority. According to this story, people who are disciplined and work hard deserve their wealth. People who are poor, in the conservative mode of thought, are not disciplined enough to work hard and deserve their poverty. Progressive modes of thought are rooted in empathy and see government as a NURTURING PARENT whose role is to protect and empower, while conservative modes of thought see government as a STRICT FATHER who rules with authority and demands discipline and independence. 
Table 1. Progressive and conservative modes of thought.

\begin{tabular}{|l|l|}
\hline Progressive modes of thought & Conservative modes of thought \\
\hline Empathy & Self-interest \\
\hline We're in this together & You're on your own, buddy \\
\hline Taxes are membership fees for society & Tax burden, tax relief \\
\hline Concern for others and the environment & Every man for himself \\
\hline Government as nurturing parent & Government as strict father \\
\hline Protection, care, empowerment & Authority, discipline \\
\hline Nature as web, nature as mother & Nature as storehouse, nature as resource \\
\hline
\end{tabular}

Based on Lakoff's theory of cognitive metaphor, Stibbe's ecolinguistics is concerned with the stories we live by about the natural world. Stibbe sees the story of neoclassical economics as our main story. This is the story of constant growth, maximizing profit, where everyone's main goal is to accumulate wealth in order to consume more. Stibbe's goal is to expose the narratives that are harmful, and draw attention to alternative, less harmful narratives. The erasure of animals from food discourse (Stibbe 2012) is an important example. Verhagen (2008) explored many different metaphors for nature that range from 'nature as a storehouse', a 'repository of resources' to 'nature as a web' or 'nature as Mother'. In different aspects of our lives, we may live by all of them depending on the context. Some are rooted in self-interest and economic prosperity ('repository of resources'), while others are about connectedness and empathy ('nature as a web'). It is easy to split the stories about nature along the conservative (self-interest) and progressive (empathy) divide (cf. Table 1).

Lakoff (2008) believes that conservatives are better at promoting their values by choosing the right metaphors while progressives do not know how to articulate the stories they live by. He makes an argument that neoliberalism is not in touch with the progressive values that are rooted in empathy because they focus on policy, facts, and statistics, and follow an outcome-oriented mode of thinking. This "hides ideas and moral principles put forth by progressives who are not neoliberals" (Lakoff 2008: 56). This results in what he calls 'incrementalism' with the effect that "neoliberals often wind up not even stating, much less fighting for, the progressive moral position" (Lakoff 2008: 57).

Lakoff's cognitive linguistics (e.g. Lakoff 2008) and Stibbe's ecolinguistics (e.g. Stibbe 2015) can explain how narratives about energy distribution are framed to appeal to everyone, even though they perpetuate neoclassical economics. Stibbe's 
approach also draws on critical discourse analysis (CDA). Traditionally associated with an 'emancipatory knowledge interest' (e.g. Habermas 1992), critical discourse analysis has recently restated its goals as an argumentative or "procedural approach" to discourse ethics (Fairclough, Fairclough 2018):

This involves a procedure for critical questioning of proposals for actions which
can integrate considerations coming from deontological, virtue and consequen-
tialist ethical perspectives. A procedural approach provides an ethical commit-
ment to impartiality in CDA, which is necessary to its status as critical social
science method. The procedure is applied in the normative critique of argu-
mentation, in explanatory critique of aspects of social practices and structures.
(Fairclough, Fairclough 2018: 170)

A procedural approach to discourse analysis means analysing discourse on both sides of an issue in order to explain the values, ideas, and discursive practices behind opposing narratives. Lakoff's cognitive linguistic approach to opposing modes of thought in the US context explains how narratives are constructed through frames, metaphors, prototypes, and images. This analysis is consistent with a procedural approach that examines discourse practices on both sides of an issue systematically. In the following section, a detailed analysis of the ballot text of Amendment 1 reveals the frames and metaphors that have been used to construct its salient narratives and expose its erasures to appeal to both conservative and progressive thought habits while hiding the real goal.

\section{The energy consumer narrative}

The foregrounded CONSUMER PROTECTION narrative that is already built into the controversial PAC name Consumers for Smart Solar dominates the amendment title and runs through the entire ballot text. In the context of solar energy, the CONSUMER narrative is paramount as it prevents the potential owners of solar devices from perceiving themselves as PRODUCERs of energy. The fact that owners of solar energy devices produce energy is erased from the narrative. This erasure of the energy production narrative (sensu Stibbe 2015) leaves the CONSUMER perspective as the salient story and, as it turns out, is the main goal of the measure. It keeps the utility customer firmly in the role of consumer. 


\section{Rights of Electricity Consumers Regarding Solar Energy Choice}

This amendment establishes a right under Florida's constitution for consumers to own or lease solar equipment installed on their property to generate electricity for their own use. State and local governments shall retain their abilities to protect consumer rights and public health, safety and welfare, and to ensure that consumers who do not choose to install solar are not required to subsidize the costs of backup power and electric grid access to those who do.

Stibbe (2015: 37) explains that "the discourse of neoclassical economics uses language in a way which creates a character labelled 'consumer', and represents consumers as egotists who are only interested in maximizing their own wellbeing, who seek satisfaction only through purchasing products, who always want to buy more, and no matter how much they consume, are never satisfied". In this neoclassical economic model, "consumers consume, workers work, investors invest, owners own. This is described as 'functionalisation' by van Leeuwen (2008, p. 42), where 'social actors are referred to in terms of an activity, in terms of something they do'. [...] Clearly, most people do not refer to themselves as 'consumers', and the classification is one imposed by the discourse of neoclassical economics" (Stibbe 2015: 36). In the context of a constitutional amendment about solar energy, voters are more likely to refer to themselves as citizens, or in this specific context, homeowners. However, the main goal is framing them as consumers.

\subsection{Consumer protection}

The narrative of CONSUMER PROTECTION taps into a set of fears that characterizes the housing and construction industry in Florida as a whole. According to Lakoff (2004), frames evoke related concepts without overtly referring to them. The concept of protection brings with it that which one needs to be protected from. To understand the fears evoked by the CONSUMER PROTECTION narrative in the context of housing and construction, it is important to understand that the Florida construction and home improvement industry is generally perceived as dangerous territory. Florida is notoriously dominated by large-scale development, while residential homeowners are usually passive consumers of housing and construction. There is an inherent expectation that any homeowner taking on a larger construction project such as the installation of solar or other renewable energy devices will be taken advantage of or experience unethical business practices from contractors.

7 Stibbe is quoting Van Leeuwen, Theo 2008. Discourse and Practice: New Tools for Critical Discourse Analysis. Oxford: Oxford UP, 2008. 
In her best-selling book Avoiding the Con in Construction, a prominent Florida contractor explains that:

[...] this business is more susceptible to fraud than many other industries. In response to the harm that can occur from flawed construction and contracting, many states enacted laws to regulate contractors and their trade. But you must know the rules of the game to benefit from the protections they afford. (Ricchi 2010: 2)

The success behind this book of horror stories of homeownership is the prevalent Floridian fear of faulty construction, low quality work, and unfair pricing. This insecurity of property owners is the central theme evoked by the CONSUMER PROTECTION narrative in the ballot text of Amendment 1. Going solar? Good luck with that!

Amendment 1 promises that "State and local governments" will protect consumers from the risks and perils they fear, but there are no special consumer protection laws for solar and other renewable energy devices and their installation. Amendment 1 is not about new rules for contractors or new laws protecting the fearful homeowner. Contractors who install solar panels are bound by the same building codes and regulations as all contractors. There are no special protections from fraud, unfair prices, or low quality associated with Amendment 1 other than the ones Floridians already have.

Ruth Wodak (2015) has recently described discourse strategies associated with 'the politics of fear' that explain how political agendas are best promoted by invoking the things people are afraid of. Floridians are afraid of contractors and construction. Lakoff considers trauma and repetition the chief mechanisms that establish the narratives we live by (Lakoff 2008: 128). Hearing the horror stories again and again is enough to grow the fear. The homeowner who has been taken advantage of once will naturally be fearful of the next home improvement project. However, endless repetition of the same narrative will cause fear even for those who have never experienced the trauma.

\subsection{The concept of choice}

Choice is an important concept in recent political discourse. It has a progressive connotation on the one hand (e.g. Pro-Choice in the context of women's health) and a free-market connotation (e.g. School Choice in the context of privatizing education) on the other hand. It calms potential fears of requirements or regulations. 


\section{Rights of Electricity Consumers Regarding Solar Energy Choice}

This amendment establishes a right under Florida's constitution for consumers to own or lease solar equipment installed on their property to generate electricity for their own use. State and local governments shall retain their abilities to protect consumer rights and public health, safety and welfare, and to ensure that consumers who do not choose to install solar are not required to subsidize the costs of backup power and electric grid access to those who do.

The concept of choice liberates the consumer from what are perceived as mandatory purchases. This idea of health insurance as a MANDATORY PURCHASE is the conservative story of universal health care. If it is a choice, you can take it or leave it. Nobody is forcing you to buy it.

Values like choice, freedom or justice are difficult to define and mean different things in the conservative or progressive modes of thought. Lakoff (2008: 177) refers to these ideas as contested concepts. Likewise, Fairclough and Fairclough (2018: 174) warn that:

Politicians from all sides of the political spectrum speak of fairness, justice and freedom, but they do not seem to mean the same thing when they do so. There is a danger, in CDA and elsewhere, of adopting a particular conception and talking about it as if it were the one and only one conception, for example defending equality on the assumption that a version of economic egalitarianism is the only legitimate way of talking about equality, hence if someone rejects economic egalitarianism then s/he is rejecting equality per se.

Ballot texts are often fraught with contested concepts, precisely because they mean different things to different people but appeal to everyone. The result is Peirce's 'inward reasoning' that relies on feelings. СногCE sounds good no matter what connotation in conjures. It adds another positive frame to the idea that Amendment 1 is about PROTECTING THE CONSUMER.

\subsection{The concept of rights}

One could say that the phrase 'establishes a right' is an overt lie if one takes the verb 'establish' to mean that the right to own or lease solar equipment did not exist before this measure. To be clear, Floridians already had the right to buy and install solar equipment. Maybe one could argue that 'establishing a right' is not the same as granting or giving a right that did not exist before? The strategy here is vagueness. 


\section{Rights of Electricity Consumers Regarding Solar Energy Choice}

This amendment establishes a right under Florida's constitution for consumers to own or lease solar equipment installed on their property to generate electricity for their own use. State and local governments shall retain their abilities to protect consumer rights and public health, safety and welfare, and to ensure that consumers who do not choose to install solar are not required to subsidize the costs of backup power and electric grid access to those who do.

The verb 'establish' is just opaque enough to make things unclear. Ruth Wodak (2015: 60) calls this discursive strategy 'calculated ambivalence. It obscures the facts and makes inference more difficult, leaving the reader to their intuition once again. The 'consumer rights' in the following sentence reinforce the CONSUMER perspective.

\subsection{Public health, safety, and welfare}

Public health, safety, and welfare are values nobody can argue with. In the progressive mode of thought, these concepts evoke the story of the progressive NURTURING PARENT government protecting and empowering citizens. But these frames also entail DANGERS and THREATS. One could say 'public health, safety, and welfare' are just positive frames that make the measure attractive. They shine like a string of lights through the fog of 'calculated ambivalence' (cf. Wodak 2015).

\section{Rights of Electricity Consumers Regarding Solar Energy Choice}

This amendment establishes a right under Florida's constitution for consumers to own or lease solar equipment installed on their property to generate electricity for their own use. State and local governments shall retain their abilities to protect consumer rights and public health, safety and welfare, and to ensure that consumers who do not choose to install solar are not required to subsidize the costs of backup power and electric grid access to those who do.

Lakoff's thought experiment "Don't think of an elephant" (cf. Lakoff 2004) explains that just mentioning the thing we want to avoid will put the idea on everyone's mind and thereby achieve the opposite. If we talk about protecting public health and safety in the context of solar panels, what is it we should be worried about? Are they safe in a hurricane? What are the potential hazards? And even though public health, safety, and welfare are a set of values nobody can argue with, by bringing health and safety into the discourse, the potential hazards are automatically part of the story, reinforcing the need for CONSUMER PROTECTION. 


\subsection{For their own use}

The phrase 'for their own use' at the end of the long first sentence of the ballot text seems almost inconsequential on a cursory first reading. Those who encounter this text only when they step into the voting booth will likely overlook its significance, just like they may not hear the clock ticking on the wall. It may seem like an unnecessary appendage. Of course, solar panels on your roof will generate electricity for your own use and not someone else's? Or do they?

\section{Rights of Electricity Consumers Regarding Solar Energy Choice}

This amendment establishes a right under Florida's constitution for consumers to own or lease solar equipment installed on their property to generate electricity for their own use. State and local governments shall retain their abilities to protect consumer rights and public health, safety and welfare, and to ensure that consumers who do not choose to install solar are not required to subsidize the costs of backup power and electric grid access to those who do.

The phrase 'for their own use' has the most profound legal implications in that it lays the foundation for a legal barrier to net metering, the concept strategically erased from the discourse. 'For their own use' sounds good especially to those who live by the EVERY-MAN-FOR-HIMSELF story that is deeply ingrained in the conservative American idea of personal freedom, self-reliance, and the SELF-MADE MAN (cf. Lakoff 2008). It is the opposite of WE'RE IN THIS TOGETHER that underlies progressive narratives of everyone paying their dues while sharing their excess that is compatible with the concept of net metering, the SHARING OF SURPLUS.

Net metering is a concept very few Americans are familiar with. It appears only 62 times in the Corpus of Contemporary American English (COCA) between 1990 and 2017, nearly half of them were in Mother Earth Magazine and the rest in similar publications ${ }^{8}$. Net metering is a mechanism that credits solar energy system owners for the electricity they add to the grid. It allows producers of alternative energy to use the net energy they produce anytime instead of when it is generated. Utilities, where net metering exists, want to keep these credits to consumers low, while consumers are looking for the best return on their investment. Models of net metering vary widely and finding the right model for an increasing number of solar energy producers added to the grid is precisely the challenge utilities were trying to come to terms with. When solar installations in the US increased dramatically between 2014 and 2015, utilities were struggling to find the right business model while maintaining their profits. All but a few states

8 See Corpus of Contemporary American English 1990-2017 at English-corpora.org. 
allowed net metering in 2016. In early 2016, Nevada had revised its policies of net metering and reduced the credits to a minimum wholesale fee per $\mathrm{kw} / \mathrm{h}$; and discussions in New York and California were threatening similar turns (Carley, Davies 2016; Martin 2016).

The Florida Public Service Commission (PSC) allows net metering and interconnection for renewable-energy systems up to $2 \mathrm{MW}$ in capacity for investorowned utilities and also requires municipal utilities and electric cooperatives to offer net metering without stipulating standards. Net metering is available to customers who generate electricity using solar energy, geothermal energy, wind energy, biomass energy, ocean energy, hydrogen, waste heat or hydroelectric power (Department of Energy). ${ }^{9}$ On their website, Florida Power and Light explained that:

Florida Power and Light's net metering program currently allows homeowners to install and connect solar energy systems to the grid and receive credit for the energy produced by their systems. FPL allows customers to install systems meeting up to 115 percent of their current energy need. Customers' credits will be applied to their energy bill, and FPL will provide monetary compensation for any extra credits not used over the course of the year in January. (Florida Power \& Light 2018)

Utilities see these credits as an unfair transfer of costs, because they are providing and maintaining the grid distribution system. Their strategy was to discourage residential solar and lay the foundation to end net metering with the calculated ambiguity of the phrase 'for their own use' in the amendment. Using the term 'net metering' would have made everyone aware of the fact that it exists. Curious voters would have searched for the term or looked it up. Instead of allowing the concept of net metering to enter the public discourse, it was strategically hidden behind the phrase 'for their own use. The authors of the ballot text purposefully erased the concept they wanted to keep out of the discourse.

The opponents of Amendment 1, a bipartisan coalition of solar advocates, solar manufacturers, and environmental organizations called Floridians for Solar Choice, simply referred to the intended barriers to net metering as 'fees' (cf. Floridians for Solar Choice fact sheet on Amendment 1) imposed on solar energy producing utility customers. Floridians for Solar Choice had actually proposed an amendment promoting net metering that never made it on the ballot.

9 Department of Energy. Florida Statutes on Net-metering, retrieved in October 2018 from https://www.energy.gov/savings/net-metering-36. 


\section{VOTEN"NOON 1.onc \\ WANT MORE SOLAR IN THE SUNSHINE STATE? VOTE NO ON AMENDMENT 1 \\ Floridians should VOTE NO on Amendment 1 for three reasons:}

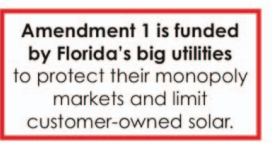

customer-owned solar.
Amendment 1 misleads Florida voters by promising rights and protections that Florida citizens already have.

Figure 3. Floridians for Solar Choice fact sheet.

Why did opponents not use the term 'net metering' in their campaign against Amendment 1 ? Why did they not introduce the main idea they wanted voters to support? Was their strategy to make the arguments against Amendment 1 easy to understand? Their three reasons to vote 'no' on Amendment one, according to their fact sheet, were

(1) that it was proposed and funded by Florida's investor-owned utilities;

(2) that it promised rights and protections Floridians already have; and

(3) that it paves the way for barriers that would penalize solar customers. (Floridians for Solar Choice fact sheet 2016)

Erasing the term 'net metering' from public discourse prevented voters from understanding precisely what utilities were trying to keep away from them.

While Floridians for Solar Choice left the concept of net metering out of their fact sheets and flyers, net metering was discussed in several articles in the Miami Herald. For instance, the Miami Herald quoted former Vice President Al Gore saying:

The things they [Consumers for Smart Solar] claim protect solar are protections you already have. But they are trying to fool you into amending your state Constitution in a way that gives them the authority to shut down net metering and do in Florida what they did in Nevada and just kill the solar industry. (Miami Herald, 11 October, 2016)

On 18 October 2016, the Miami Herald reported of a leaked audio recording of Sal Nuzzo, policy director of the James Madison Institute, a supporter of Amendment 1. At a conservative convention in Nashville on 2 October 2016, Nuzzo was recorded calling the amendment "an incredibly savvy maneuver" that "would 
completely negate anything they [pro-solar interests] would try to do either legislatively or constitutionally down the road" (Miami Herald, 18 October 2016).

The following day, Elon Musk alerted his five million followers on Twitter about the "calculated attempt to deceive Florida voters about solar vote uncovered by Miami Herald" (Elon Musk Twitter post 10/19/2016 9:44 am). The real goal for utilities and energy corporations behind Amendment 1, according to another Miami Herald article, was:

[...] to push through proposals that weaken the state's net-metering laws that allow homeowners to be reimbursed for the excess energy their solar panels generate, and end tax rebates to solar customers. The utilities gave at least $\$ 9$ million to legislative campaigns and Gov. Rick Scott to influence their outcome. (Miami Herald, 8 November, 2016)

\subsection{Non-solar customers subsidizing solar users? Opposition to the sharing economy}

The second sentence, longer and even lower in readability than the first one, ends with the story that regular utility customers are somehow SUBSIDIZING backup power and grid access for solar generating customers.

\section{Rights of Electricity Consumers Regarding Solar Energy Choice}

This amendment establishes a right under Florida's constitution for consumers to own or lease solar equipment installed on their property to generate electricity for their own use. State and local governments shall retain their abilities to protect consumer rights and public health, safety and welfare, and to ensure that consumers who do not choose to install solar are not required to subsidize the costs of backup power and electric grid access to those who do.

These costs are in fact the loss in revenue utilities will incur by giving net-metering customers credit for the energy they are sending back into the grid. To frame this loss in revenue as subsIDIEs coming from those who do not choose to install renewable energy devices, once again, erases the SHARING OF SURPLUS narrative and reframes it as subsidies for grid access and maintenance. Recall that Nevada had just revised its net-metering policies and reduced the credits to a minimum whole-sale fee per $\mathrm{kW} / \mathrm{h}$ in early 2016 because the surge in solar installations from the previous year had rendered their existing model unprofitable (Martin 2016). Similar challenges in New York and California were met with much stronger commitment to renewable energy. The challenge to find new models of energy distribution is the real issue behind Amendment 1, but the ballot text frames the 
problem simply as their promise that customers who do not want solar panels will never have to SUBSIDIZE solar energy.

One could argue that the States of California and New York are actually subsidizing renewable energy by making it possible for more customers to go solar. If grid access and maintenance ultimately increase costs, one could say that it is factually true that all customers are paying for the energy generated by solar customers. This is the kind of SHARING ECONOMY that goes against the conservative EVERY MAN FOR HIMSELF model and the neoclassical economics that, as Stibbe (2015: 46) explains, "[outlaws] sustainability, sharing and survival [...] in the name of market competitiveness and market efficiency".

\section{Energy discourse reframed for the sharing economy}

As an alternative to neoclassical economics, Lakoff recommends progressives should reframe our air and water as common wealth. This was a central idea in Peter Barnes' Sky Trust proposal (Barnes 2001). In this story, we own the air and we own the water and whoever pollutes it owes us payment for the damage. Barnes called this POLLUTION PERMITs. Whoever protects our resources by producing solar or other renewable energy earns CREDIT. It entails the narrative of the SHARING OF SURPLUS that is the fundamental principle of a SHARING ECONOMY.

Such alternative distribution systems already exist in other countries, most notably Germany and the Netherlands. The CEO of the German company Sonnenbatterie describes this model as the "Airbnb of energy distribution" (Martin 2015), where they simply supply the storing and distribution of excess solar energy produced by owners of clean energy devices for consumers at set rates. This SHARING ECONOMY model is to utilities what Airbnb is to the hotel industry. Similar mechanisms of regulating companies like Airbnb or Uber offer comparable examples of push back from the dominant industries through lobbying for restrictive laws and regulations. Taxi companies fight against Uber. Hotels fight against Airbnb. Utility companies fight against net metering for renewable energy. The strategy of Amendment 1 was to lay the foundation for barriers to net metering by erasing the concept itself from public discourse. Opponents of Amendment 1 would have done well to use the term 'net metering' in their campaigns more prominently simply to draw attention to the fact that it exists in most states in the US, including Florida.

Instead of framing their values, opponents used the economic frame of FEES imposed on solar users and missed an important opportunity to educate the public about net metering and thereby reframe the debate. They failed to articulate their 
values clearly and then propose the policies that represent those values. Lakoff (2008: 169) calls this 'cognitive policy'.

When Floridians for Solar Choice filed a complaint about the Amendment 1 ballot text being deceptive, the Florida Supreme Court rejected the complaint with a 4-3 vote, arguing that it was "clearly worded and compliant with regulations" (Greenfield Reporter, 31 March 2016).

After Amendment 1 was narrowly defeated, an article in the Miami Herald quoted the spokesperson of Floridians for Solar Choice, Tory Perfetti, saying "We defeated one of the most egregious and underhanded attempts at voter manipulation in this state's history" (Klas 2016a).

\section{Conclusion}

Ballot texts and the social practices associated with them are worth analysing in order to understand how they represent political measures and their consequences. Ballot texts are notoriously low in readability and high in deceptive use of contested concepts, frames, and metaphors. A critical analysis of the visual ad campaign and ballot text revealed how the true objectives were hidden behind positive environmental and consumer protection narratives. By strategically erasing the concept of net metering from the discourse, an anti-solar amendment was successfully framed as a pro-consumer measure. The direct legal implications (i.e. legal barriers to net metering) and rights concerning alternative energy distribution systems were intentionally erased. The ballot text reinforces the basic narrative of neoclassical economics, casting the voter as consumer of energy, in an effort to deny and discourage the sharing of surplus that characterizes alternative energy distribution by erasing it from the discourse.

\section{References}

Barnes, Peter 2001. Who Owns the Sky? Our Common Assets and the Future of Capitalism. Washington: Island Publishers.

Carley, Sanya; Davies, Lincoln L. 2016. Nevada's net energy metering experience: The making of a policy eclipse? Brookings Mountain West Publications 44: 1-29.

EP $=$ Peirce, Charles Sanders 1992-1998.

Fairclough, Isabela; Fairclough, Norman 2012. Political Discourse Analysis: A Method for Advanced Students. London: Routledge. https://doi.org/10.4324/9780203137888

Fairclough, Norman; Fairclough, Isabela 2018. A procedural approach to ethical critique in CDA. Critical Discourse Studies 15(2): 169-185. https://doi.org/10.1080/17405904. 2018.1427121 
Greenfield Reporter 2016. Florida voters will get a chance to vote this fall on solar power initiative that has been placed on the ballot with the backing of the state's largest power companies. March 31, 2016.

Habermas, Jürgen 1992. Faktizität und Geltung: Beiträge zu einer Diskurstheorie des Rechts und des demokratischen Rechtsstaats. Frankfurt: Suhrkamp.

Klas, Mary Ellen 2016a. Florida voters say no to misleading solar amendment. Miami Herald (8 November, 2016, updated 9 November, 2016).

Klas, Mary Ellen 2016b. Florida Utilities spend millions to make case to limit rooftop solar. Miami Herald (1 November, 2016, updated 3 November, 2016).

Lakoff, George 2004. Don't Think of an Elephant. New York: Penguin.

Lakoff, George 2008. The Political Mind: A Cognitive Scientist's Guide to Your Brain and Its Politics. New York: Penguin.

Lakoff, George 2010. Why it matters how we frame the environment. Environmental Communication 4(1): 70-81. https://doi.org/10.1080/17524030903529749

Martin, Richard 2015. Battles over Net-metering cloud the future of roof-top solar. MIT Technology Review. December 29, 2015.

Martin, Richard 2016. Battles over Net-metering cloud the future of roof-top solar. MIT Technology Review. January 5, 2016.

Miami Herald. October 11 2016. Gore blasts 'phoney baloney' solar Amendment 1 on Florida ballot.

Miami Herald. October 18 2016. Insider reveals deceptive strategy behind Florida’s solar amendment.

Miami Herald Editorial Board 2016. Amendment 4: Vote Yes on this beneficial solar proposal on Aug. 3. (9 August, 2016, updated 13 August, 2016.)

Muro, Mark; Saha, Devashree 2016. Rooftop solar: Net metering is a net benefit. (Brookings Advanced Industries Series. No. 91.) 23 May, 2016.

Musk, Elon 2016. Twitter post 10/19/2016 9:44 am.

Peirce, Charles S. 1992-1998[1894]. What is a sign?. In: The Essential Peirce. Vol. 2. (Houser, Nathan; Kloesel, Christian J. W., eds.) Bloomington: Indiana University Press, 4-10. [In-text references are to EP, followed by volume and page numbers.].

Peirce, Charles S. 1992-1998 [1895]. Of reasoning in general. In: The Essential Peirce. Vol. 2. (Houser, Nathan; Kloesel, Christian J. W., eds.) Bloomington: Indiana University Press, 11-26. [In-text references are to EP, followed by volume and page numbers.].

Ricchi, Kia 2010. Avoiding the Con in Construction. How to Plan for Hassle-Free Home Building, Renovation \& Repair. St. Could: Centerline Production Inc.

Stibbe, Arran 2012. Animals Erased: Discourse, Ecology, and Reconnections with the Natural World. Middletown: Wesleyan University Press.

Stibbe, Arran 2015. Ecolinguistics: Language, Ecology, and the Stories We Live By. London: Routledge.

Verhagen, Frans C. 2008. Worldviews and metaphors in the human-nature relationship: An ecolinguistic exploration through the ages. Language and Ecology 2(3): 1-19.

Wodak, Ruth 2015. The Politics of Fear: What Right-Wing Populist Discourses Mean. London: Sage. https://doi.org/10.4135/9781446270073 


\section{Обсуждение солнечной энергии в «Солнечном штате»}

Исследование рассматривает конституционные поправки Флориды 2016 года, касающиеся использования солнечной энергии и ее доли в общем энергоснабжении. После значительного роста количества солнечных панелей в 2014-2015 гг. коммунальные службы нескольких штатов США столкнулись с проблемой сохранения прежних бизнес-моделей. Предвидя аналогичные проблемы во Флориде, коммунальные предприятия и энергетические корпорации содействовали внесению поправок в Конституцию. Статья анализирует ряд текстов от рекламных щитов и листовок до текстов на бюллетенях. Основываясь на феноменологических категориях Пирса, а также когнитивной лингвистике Лакоффа и эколингвистике Стиббе, статья показывает, как истинные цели поправки были скрыты за дискурсами о защите окружающей среды и потребителей. Данное исследование показывает, что, оставив ключевые понятия (особенно сетевые измерения, net metering) вне дискурса, текст бюллетеня успешно представил поправку, направленную против применения солнечной энергии, как меру в защиту потребителей, скрывая при этом прямые правовые последствия, связанные с распределением альтернативной энергии. В частности, данное исследование объясняет проблему неприятия раздела излишков в контексте неоклассической экономики в качестве ключевого фактора формирования представлений об альтернативном распределении энергии.

\section{Päikeseenergia diskursus Päikesepaiste osariigis}

Florida 2016. aasta konstitutsioonimuudatusi käsitlevas juhtumiuuringus analüüsitakse semiootilisi võtteid ja mehhanisme päikeseenergiat puudutava avaliku arvamuse ning energiajaotuse kohta käivate uskumuste kujundamisel. Pärast üleriigilist katusele kinnitatavate päikesepaneelide leviku kasvu ajavahemikus 2014-2015 seisid mitme USA osariigi kommunaalmajandusettevõtted silmitsi oma ärimudelite ees seisvate probleemidega. Ennetamaks selliste probleemide esiletõusu Floridas tegid kommunaalmajandusettevõtted ja energiakorporatsioonid ettepanekuid konstitutsiooni muutmiseks. Käesolev semiootiline analüüs liigub koos hääletajaga plakatite ja flaierite juurest hääletustekstini. Kampaania kriitiline analüüs, mis lähtub Peirce'i fenomenoloogilistest kategooriatest, näitab, kuidas paranduste eesmärke peideti positiivsetesse keskkonnasõbralikesse ning tarbijakaitsenarratiividesse. Sügavamat analüüsi toetavad Lakoffi kognitiivne lingvistika ja Stibbe’i ökolingvistika. Uurimusest nähtub, et jättes diskursusest välja võtmemõisted (eriti netomõõtmise, 'net metering'), raamistas hääletustekst päikeseenergia vastu suunatud muudatuse edukalt tarbijasõbraliku meetmena, varjates otseseid seadusandlikke implikatsioone alternatiivse energiajaotuse suhtes. Eelkõige selgitatakse uurimuses vastuseisu ülejäägi jagamisele uusklassikalise majanduse kontekstis kui võtmetegurit alternatiivset energiajaotust puudutavate uskumuste kujundamises. 